\title{
Use of Selected Essential Oils to Control Aflatoxin Contaminated Stored Cashew and Detection of Aflatoxin Biosynthesis Gene
}

\author{
Abeer R. M. Abd El-Aziz, ${ }^{1}$ Mohamed A. Mahmoud, ${ }^{2}$ \\ Monira R. Al-Othman, ${ }^{1}$ and Munirah F. Al-Gahtani ${ }^{1}$ \\ ${ }^{1}$ Botany and Microbiology Department, College of Science, King Saud University, Riyadh 1145, Saudi Arabia \\ ${ }^{2}$ Plant Pathology Research Institute, Agricultural Research Center, Giza 12619, Egypt \\ Correspondence should be addressed to Abeer R. M. Abd El-Aziz; aabdelaziz@ksu.edu.sa
}

Received 23 August 2014; Revised 22 December 2014; Accepted 23 December 2014

Academic Editor: Valdir Cechinel Filho

Copyright (C) 2015 Abeer R. M. Abd El-Aziz et al. This is an open access article distributed under the Creative Commons Attribution License, which permits unrestricted use, distribution, and reproduction in any medium, provided the original work is properly cited.

\begin{abstract}
Aspergillus spp. associated with cashew from the regions of Riyadh, Dammam, and Abha were isolated and three different culture media were used to qualitatively measure aflatoxin production by Aspergillus via UV light ( $365 \mathrm{~nm})$, which was expressed as positive or negative. The obtained data showed that six isolates of A. flavus and four isolates of A. parasiticus were positive for aflatoxin production, while all isolates of $A$. niger were negative. Five commercially essential oils (thyme, garlic, cinnamon, mint, and rosemary) were tested to determine their influence on growth and aflatoxin production in A. flavus and A. parasiticus by performing high-performance liquid chromatography (HPLC). The results showed that the tested essential oils caused highly significant inhibition of fungal growth and aflatoxin production in A. flavus and A. parasiticus. The extent of the inhibition of fungal growth and aflatoxin production was dependent on the type and concentration of essential oils applied. The results indicate that cinnamon and thyme oils show strong antimicrobial potential. PCR was used with four sets of primer pairs for nor-1, omt-1, $v e r-1$, and aflR genes, enclosed in the aflatoxin biosynthetic pathway. The interpretation of the results revealed that PCR is a rapid and sensitive method.
\end{abstract}

\section{Introduction}

Cashew nut (Anacardium occidentale L.) is characterized by the high percentage of carbohydrates and lipids which facilitates attacking them by moulds, specifically Penicillium and Aspergillus [1]. Aspergillus flavus and Aspergillus parasiticus are two of the most important toxigenic moulds [2]. The worldwide production of cashew is 4152315 (tonnes), area harvested (Ha) 5313415, and this crop yields $7815(\mathrm{Hg} / \mathrm{Ha})$ [3]. The aflatoxins are a group of chemically similar toxic fungal metabolites (mycotoxins) produced by genus Aspergillus. Aflatoxins are highly toxic compounds and can cause chronic toxicity in humans and animals. Aflatoxins may be present in a wide range of many food commodities, as nuts [4]. Many factors are influencing aflatoxin production during storage such as moisture, storage temperature, availability of oxygen, and lipids content [5]. There are four kinds of aflatoxins (B1, B2, G1, and G2) whereas aflatoxin B1 is the toxic kind. The presence of Aspergillus in stored cashew nuts appears in deterioration, discolouration, and bad odour [6]. Currently, synthetic chemicals are not used to manage mycotoxin production which cause harmful effects on consumers [7]. Recent trends toward natural product such as essential oil lead to safe and acceptable method. Many approaches investigated to manage aflatoxin production using essential oils [8-12].

The aims of the recent study were therefore to evaluate the effect of essential oils on the dry weight and aflatoxin production by Aspergillus spp. as well as to estimate the presence and absence of the PCR products corresponding to amplification of aflD, aflM, aflP, aflR, and aflS genes in aflatoxigenic and nonaflatoxigenic $A$. flavus isolates isolated from stored cashew.

\section{Materials and Methods}

2.1. Collection of Samples. Fifteen samples of cashew were collected randomly from different markets in three locations 
from Saudi Arabia (Riyadh, Dammam, and Abha) during 2012 for this experimental work. The samples were stored at $2^{\circ} \mathrm{C}$ until used [13].

2.2. Isolation, Purification, and Identification of Pathogen. Samples were surface sterilized with 5\% sodium hypochlorite solution for one minute; then wash these samples three times with sterilized distilled water. Four pieces were placed on the surface of potato dextrose agar Petri dishes with three replicated times. Petri dishes were incubated at $25^{\circ} \mathrm{C}$ for 7 days. Isolates were purified by single spore methods. The identification of Aspergillus flavus and A. parasiticus isolates was confirmed by Regional Center of the Fungi and their Applications, Al-Azhar University, Cairo, Egypt.

2.3. Detection of Aflatoxin Production in Different Culture Media via Fluorescence (UV). Three different media (potato dextrose agar (PDA), Czapek agar (CZ), and malt extract agar (MEA)) were used for detection of aflatoxin based on fluorescence [16]. Where the plates were incubated at $25^{\circ} \mathrm{C}$ for 4 days in the dark, the presence or absence of fluorescence in the agar surrounding the growing Aspergillus colonies was determined by exposing the Petri dishes to ultraviolet light $(365 \mathrm{~nm})$ and expressed as positive or negative according to [17].

\subsection{Effect of Essential Oils on Growth and Aflatoxin Produced} by Aspergillus spp. Antiaflatoxigenic efficacy values of each tested oil were determined using SMKY liquid medium (sucrose, $20 \mathrm{~g}$; magnesium sulfate, $0.5 \mathrm{~g}$; potassium nitrate, $3 \mathrm{~g}$; yeast extract, $7 \mathrm{~g}$; and distilled water, $1000 \mathrm{~mL}$ ) [18]. The surfactant (25\% Tween in sterile water) was added to oils; then different doses of each oil $(1,2$, and $4 \%)$ were prepared and added to media; the flasks were inoculated with discs of $6 \mathrm{~mm}$ diameter of the toxigenic Aspergillus spp. at 25 $\pm 1^{\circ} \mathrm{C}$ for 7 days [7]. Three replicates were performed for each concentration and control was carried out with Tween 80 [19]. After incubation, content of each flask was filtered (Whatman, number 1) and biomass of filtered mycelium was dried at $70^{\circ} \mathrm{C}$ for 4 days till their weights remain constant. For aflatoxins extractions, the filtrates of each flask were treated three times with $50 \mathrm{~mL}$ of chloroform in a separating funnel then dehydrated with anhydrous sodium sulfate and evaporated on water bath at $50^{\circ} \mathrm{C}$ under vacuum. The residues were dissolved in $10 \mathrm{~mL}$ methanol [20].

\subsection{Determination of Aflatoxins by High-Performance Liquid Chromatography (HPLC)}

2.5.1. Standard and Calibration Preparation. B1, B2, G1, and G2 (1 mg) aflatoxin standards were purchased from Sigma (St. Louis, MO, USA). The stock solutions $\left(10 \mu \mathrm{g} \mathrm{mL}^{-1}\right)$ and working solutions $\left(1 \mu \mathrm{g} \mathrm{mL}^{-1}\right)$ were prepared in methanol (HPLC), with assay $>99.9 \%$ (Sigma).

2.5.2. Sample Preparation. The sample was passed through a $0.45 \mu \mathrm{m}$ microfilter. Analysis of compounds was performed on HPLC model (model PerkinElmer series 200 UV/VIS) with a C18 column with an internal diameter of $300 \mathrm{~mm} \times$ $3.9 \mathrm{~mm}, 4$ micron. The HPLC was equipped with an UV detector and fluorescence with $365 \mathrm{~nm}$ excitation and 430 emission wavelengths. The mobile phase consists of methanol : acetic acid: water $(20: 20: 60 \mathrm{v} / \mathrm{v} / \mathrm{v})$. The total run time for the separation was approximately $25 \mathrm{~min}$ at a flow rate of $1 \mathrm{~mL} / \mathrm{min}$ [21]. The aflatoxin inhibition was calculated as follows:

$$
\% \text { inhibition }=\left[\frac{A-a}{A}\right] \times 100
$$

where " $A$ " is aflatoxin in the control and " $a$ " is aflatoxin in the treated sample.

2.6. Extraction of DNA from Aspergillus Isolates. Aspergillus isolates were cultured on double layer media in $50 \mathrm{~mm}$ Petri dishes, one solid and the other liquid. Base media, solid, was potato dextrose agar as a film, and the top media, liquid, was peptone yeast glucose (PYG, $1200 \mu \mathrm{L})$ and was then incubated at $25^{\circ} \mathrm{C}$ for two days. Genomic DNA extraction was according to $[22]$.

2.7. PCR Assay for Four Aflatoxins Biosynthesis Genes. PCR parameters followed those reported by [14]. PCR was performed in $25 \mu \mathrm{L}$ containing $2.5 \mu \mathrm{L}$ of $10 \mathrm{X}$ PCR buffer, $0.75 \mu \mathrm{L}$ of $25 \mathrm{mM} \mathrm{MgCl}_{2}, 0.5 \mu \mathrm{L}$ of $10 \mathrm{mM}$ dNTPs, $0.625 \mu \mathrm{L}$ of each primer, $5 \mathrm{U}$ Taq DNA polymerase, $2 \mu \mathrm{L}$ of extracted DNA as template, and $17.5 \mu \mathrm{L}$ of sterile distilled water. A total of 35 PCR cycles with the following temperature regimen was performed: $95^{\circ} \mathrm{C}, 1 \mathrm{~min} ; 65^{\circ} \mathrm{C}, 30 \mathrm{~s}$; and $72^{\circ} \mathrm{C}, 30 \mathrm{~s}$ for the first cycle and $94^{\circ} \mathrm{C}, 30 \mathrm{~s} ; 65^{\circ} \mathrm{C}, 30 \mathrm{~s}$; and $72^{\circ} \mathrm{C}, 30 \mathrm{~s}$ for the next 34 cycles. Genes $a f l D$, aflM, aflP, and $a f l R$ were tested in all isolates using the primer pairs listed in Table 1.

2.8. Statistical Analysis. All of the data from three independent replicate trials were subjected to analysis using Statistical Package for the Social Sciences (SPSS) 10.0 statistical software (Chicago, USA). The data are reported as the mean \pm standard deviations, and significant differences between mean values were determined with Duncan's multiple range test $(P<$ 0.05), followed by one-way ANOVA.

\section{Results}

3.1. Detection of Aflatoxins Produced by Aspergillus spp. Isolates from Cashews from Riyadh, Dammam, and Abha via UV Light. Data in Table 2 show that three isolates of $A$. niger, two isolates of $A$. parasiticus, and six isolates of $A$. flavus were isolated from Riyadh and detected under UV light whereas three isolates (RC4, RC5, and RC10) of Aspergillus spp. were expressed as positive for aflatoxin production. In Dammam, four isolates of $A$. niger, two isolates of $A$. parasiticus, and six isolates of $A$. flavus were isolated and detected under UV light whereas four isolates (DC5, DC6, DC7, and DC8) of Aspergillus spp. were expressed as positive for aflatoxin production. In Abha, three isolates of $A$. niger, two isolates of A. parasiticus, and five isolates of A. flavus were isolated 
TABLE 1: Details of the target genes, primer sequences, and expected product length in base pairs (bp) for PCR.

\begin{tabular}{lccc}
\hline Primer pair & Gene & Primer sequence $\left(5^{\prime} \rightarrow 3^{\prime}\right)$ & PCR product size $(\mathrm{bp})$ \\
\hline Nor-1F & aflD $(\text { nor }-1)^{\mathrm{a}}$ & ACCGCTACGCCGGCACTCTCGGCAC & 400 \\
Nor-1R & & GTT GGCCGCCAGCTTCGACACTCCG & Refence \\
Ver-1F & aflM $($ ver-1 $)$ & GCCGCAGGCCGCGGAGAAAGTGGT & 537 \\
Ver-1R & & GGGGATATACTCCCGCGACACAGCC & {$[14]$} \\
Omt-1F & aflP $($ omt -1$)$ & GTGGACGGACCTAGTCCGACATCAC & 797 \\
Omt-1R & & GTCGGCGCCACGCACTGGGTTGGGG & 1032 \\
aflR-F & aflR & TATCTCCCCCCGGGCATCTCCCGG & \\
aflR-R & & GTCGGCGCCACGCACTGGGTTGGGG & \\
\hline
\end{tabular}

${ }^{\mathrm{a}}$ Aflatoxin biosynthetic genes are named as proposed by [15]; old names are reported in brackets.

TABLE 2: Detection of aflatoxins produced by Aspergillus spp. isolates from cashews via UV light.

\begin{tabular}{|c|c|c|c|c|c|}
\hline \multirow{2}{*}{ Region } & \multirow{2}{*}{ Isolates code } & \multirow{2}{*}{ Aspergillus spp. } & \multicolumn{3}{|c|}{ Culture media } \\
\hline & & & Yeast extract & Czapek-Dox agar & $\mathrm{PDA}+\mathrm{NaCl}$ \\
\hline Riyadh & $\mathrm{RC1}$ & A. niger & - & - & - \\
\hline Riyadh & $\mathrm{RC} 2$ & A. niger & - & - & - \\
\hline Riyadh & $\mathrm{RC} 3$ & A. niger & - & - & - \\
\hline Riyadh & $\mathrm{RC} 4$ & A. flavus & + & + & + \\
\hline Riyadh & $\mathrm{RC} 5$ & A. flavus & - & + & - \\
\hline Riyadh & RC6 & A. flavus & - & - & - \\
\hline Riyadh & $\mathrm{RC} 7$ & A. flavus & - & - & - \\
\hline Riyadh & $\mathrm{RC} 8$ & A. flavus & - & - & - \\
\hline Riyadh & RC9 & A. flavus & - & - & - \\
\hline Riyadh & $\mathrm{RC} 10$ & A. parasiticus & + & + & + \\
\hline Riyadh & $\mathrm{RC} 11$ & A. parasiticus & - & - & - \\
\hline Dammam & $\mathrm{DCl}$ & A. niger & - & - & - \\
\hline Dammam & DC2 & A. niger & - & - & - \\
\hline Dammam & DC3 & A. niger & - & - & - \\
\hline Dammam & DC4 & A. niger & - & - & - \\
\hline Dammam & DC5 & A. parasiticus & + & - & - \\
\hline Dammam & DC6 & A. parasiticus & - & + & - \\
\hline Dammam & DC7 & A. flavus & + & - & - \\
\hline Dammam & DC8 & A. flavus & + & - & - \\
\hline Dammam & DC9 & A. flavus & - & - & - \\
\hline Dammam & DC10 & A. flavus & - & - & - \\
\hline Dammam & DC11 & A. flavus & - & - & - \\
\hline Dammam & DC12 & A. flavus & - & - & - \\
\hline Abha & $\mathrm{ACl}$ & A. flavus & - & - & - \\
\hline Abha & AC2 & A. flavus & + & - & - \\
\hline Abha & AC3 & A. flavus & - & - & - \\
\hline Abha & $\mathrm{AC} 4$ & A. flavus & + & - & - \\
\hline Abha & AC5 & A. flavus & - & - & - \\
\hline Abha & AC6 & A. niger & - & - & - \\
\hline Abha & AC7 & A. niger & - & - & - \\
\hline Abha & AC8 & A. niger & - & - & - \\
\hline Abha & AC9 & A. parasiticus & - & - & + \\
\hline Abha & $\mathrm{AC} 10$ & A. parasiticus & + & + & - \\
\hline
\end{tabular}




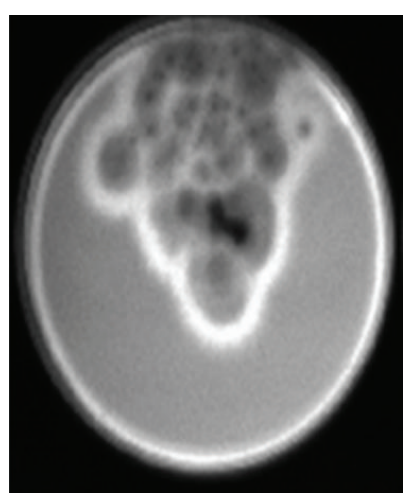

(a)

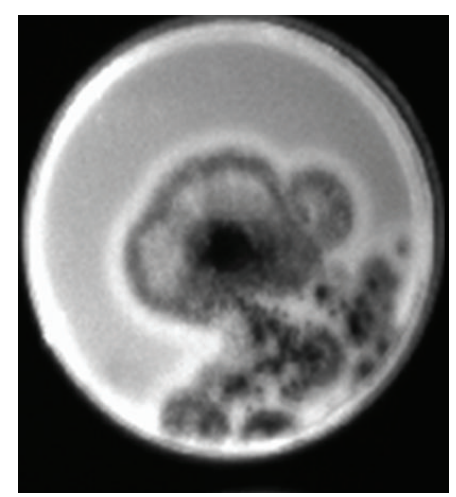

(b)

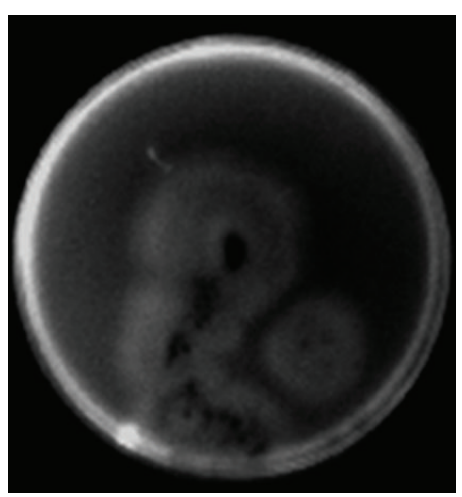

(c)

FIGURe 1: Aflatoxigenic strains of A. flavus (a), A. parasiticus (b), and A. niger (c) visualized under $365 \mathrm{~nm}$ UV light. The white ring around colonies of aflatoxigenic strains displays faint blue fluorescence.

and detected under UV light whereas three isolates (AC2, AC4, and AC10) of Aspergillus spp. were expressed as positive for aflatoxin production. Example of non-aflatoxigenic and aflatoxigenic isolates are shown in Figure 1.

\subsection{Effect of Five Essential Oils at Three Different Doses on Dry} Weight of A. flavus and A. parasiticus Isolated from Cashews. Effect of different doses of essential oils on dry weight of mycelia after incubation at $25 \pm 1^{\circ} \mathrm{C}$ for 7 days of $A$. flavus and $A$. parasitica. The all tested essential oils appeared more effective on the growth at three tested doses compared to control; \% inhibition of dry weight decreased with increasing doses of all treatments by essential oils.

Tables 3 and 4 show that the highest growth inhibition rate of the tested fungi was isolated from cashews observed with the cinnamon oil and thyme oil at $4 \%$ in both A. flavus and $A$. parasiticus ranged from 50.4 to $72.7 \%$ and 44.2 to $70.1 \%$, respectively. However, growth was slightly inhibited at the lower levels. Statistical results showed that kind and amount of essential oils have a significant influence on dry weight; $P<0.05$.

\subsection{Effect of Five Essential Oils at $4 \%$ on Aflatoxin B $(\mu \mathrm{g} / \mathrm{mL})$} Produced by A. flavus That Were Isolated from Cashews. Data in Table 5 obtained that five tested essential oils that lead to a decrease in aflatoxins (B) were produced by $A$. flavus when compared with control. Thyme oil and cinnamon oil were the highest effective essential oils on inhibition of aflatoxin B which ranged from 53.5 to 86 and 59.2 to $78.7 \%$, respectively. Mint oil gave the third rank followed by rosemary oil; inhibition ranged from 46.1 to 71.9 and 38.6 to $64.4 \%$, respectively, whereas the least effective essential oil was garlic oil (ranged from 28.5 to $62.8 \%$ ). The results indicate that the tested toxigenic fungi are sensitive to the tested five essential oils; particularly isolate number AC2 was more sensitive to any tested oils: thyme, cinnamon, mint, rosemary, and garlic (86.0, 78.5, 71.9, 64.4, and 62.8\%, resp.), while the least of inhibition was observed in isolate number AC4 (28.5\%) when treated with garlic oil.
3.4. Effect of Five Essential Oils at $4 \%$ on Aflatoxin $G(\mu g / m L)$ That Were Produced by A. flavus Isolated from Cashews. Data in Table 6 obtained that cinnamon oil was the highest effective essential oil on inhibition of aflatoxin $\mathrm{G}$ followed by thyme oil at $4 \%$ which leads to the highest level of inhibition ranging from 65.5 to 87.3 and 58.8 to $67.3 \%$, respectively. Treatment with cinnamon oil leads to complete inhibition of aflatoxin G2 produced by isolates number AC4. Mint oil gave the third rank followed by Rosemary oil; inhibition ranged from 55.1 to 67.7 and 45.3 to $60.2 \%$, respectively, whereas garlic oil gave the least (34.1 to $45.8 \%)$. In addition to that, the results indicate that the highest level of inhibition \% was observed in isolates number AC2, while the least of inhibition was observed in isolates number DC6.

3.5. Effect of Five Essential Oils at $4 \%$ on Aflatoxin B $(\mu \mathrm{g} / \mathrm{mL})$ Produced by A. parasiticus That Were Isolated from Cashews. Data in Table 7 obtained that five tested essential oils which lead to a decrease in aflatoxins (B) were produced by $A$. parasiticus when compared with control. Thyme oil and cinnamon oil were the highest effective essential oils on inhibition of aflatoxin B which ranged from 60.8 to 71.6 and 67.3 to $70.7 \%$, respectively. Mint oil and rosemary oil gave the third rank; inhibition ranged from 52.9 to 57.7 and 48.7 to $59.8 \%$, respectively, whereas garlic essential oil ranged from 40.8 to $47.9 \%$. In addition to that, treatment with cinnamon oil leads to complete inhibition on production of aflatoxin B2 in two isolates numbers RC10 and DC5.

\subsection{Effect of Five Essential Oils at $4 \%$ on Aflatoxin $G(\mu \mathrm{g} / \mathrm{mL})$} That Were Produced by A. parasiticus Isolated from Cashews. Data in Table 8 obtained that cinnamon oil was the highest effective essential oil on inhibition of aflatoxin $G$ followed by thyme oil at $4 \%$ which leads to the highest level of inhibition ranging from 57.1 to 70.8 and 52.4 to $61.2 \%$, respectively. Rosemary oil gave the third rank followed by mint oil; inhibition ranged from 50.2 to 65.3 and 51 to $58.3 \%$, respectively, whereas garlic oil gave the least (27.9 to $47.4 \%$ ). In addition to that, the results indicate that the highest level of inhibition of aflatoxin $G$ was observed in isolate number 


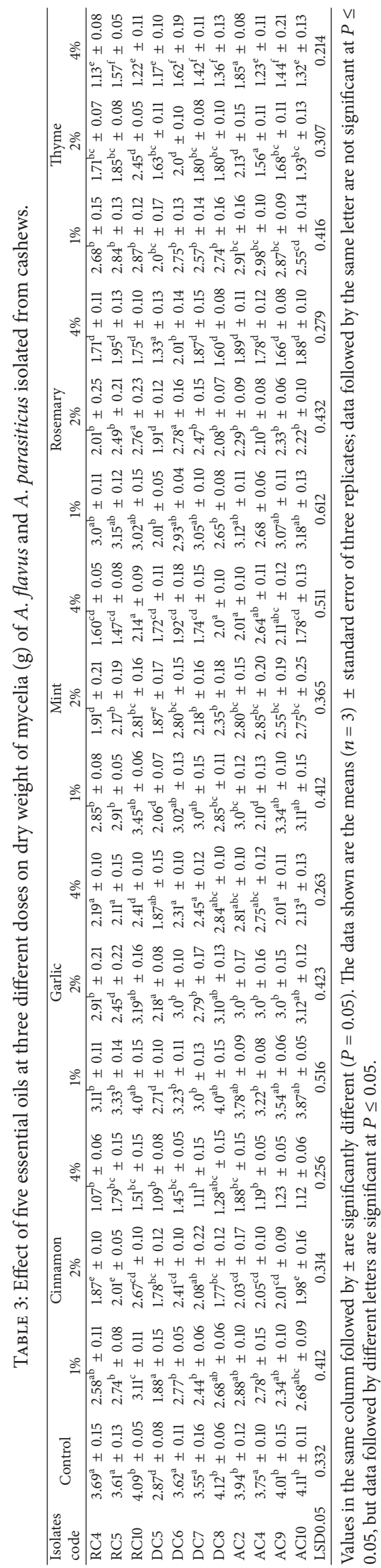




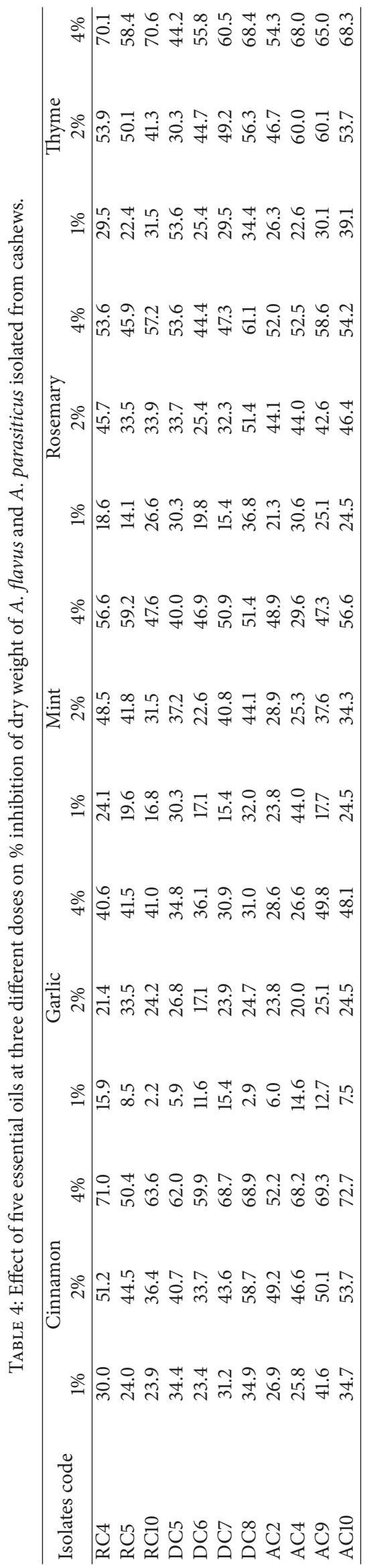




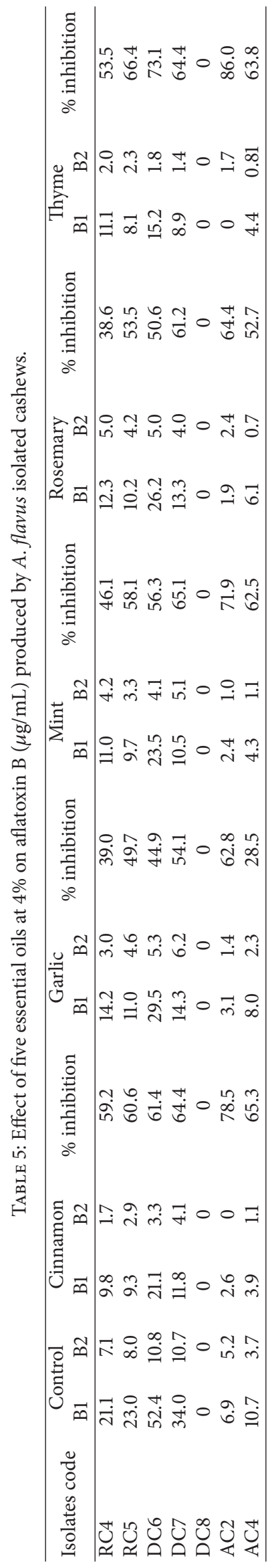




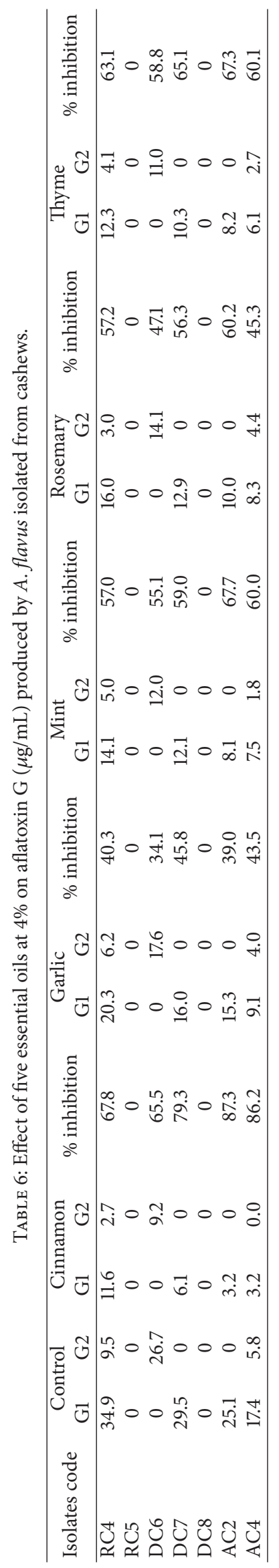




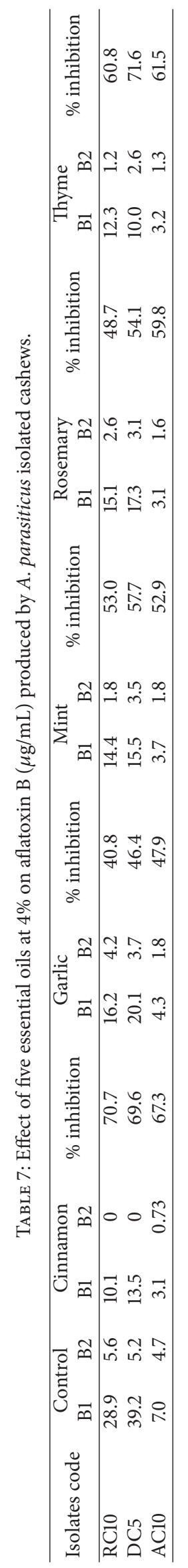




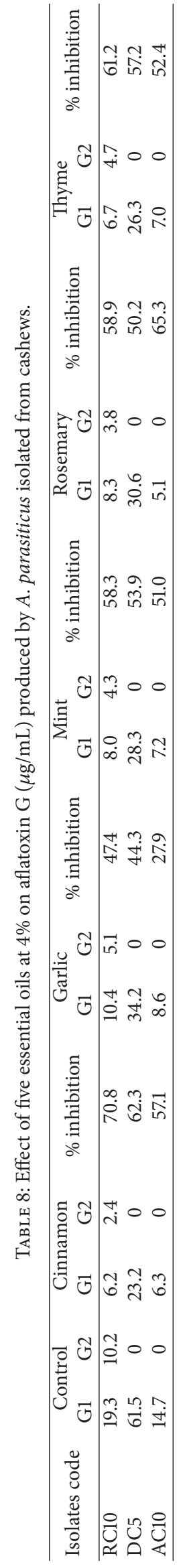




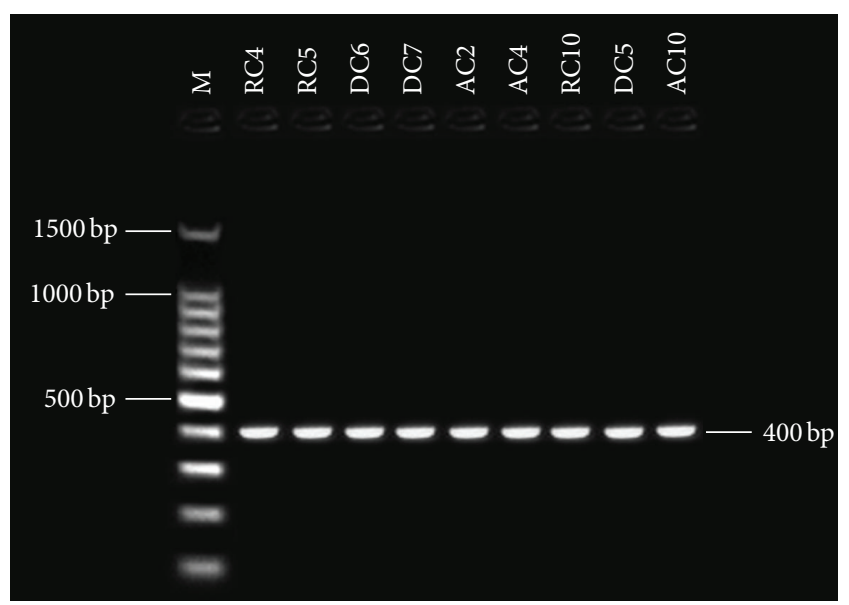

FIgURe 2: Gel electrophoresis analysis PCR products using nor-1 primer with $400 \mathrm{bp}$, lanes from RC4 to AC4 (A. flavus), lanes from RC10 to AC10 (A. parasiticus), and lane M: 100 bp DNA ladder size marker.

RC10 at most cases, while the least inhibition was observed in isolate number AC10 when treated with any tested essential oil except treatment with rosemary oil.

3.7. Detection of Four Aflatoxins Biosynthesis Genes. Primers pairs were used for this study to target four aflatoxin biosynthetic genes: the one regulatory gene $a f R$ and the structural genes nor-1 (aflD), ver-1 (aflM), and omt-1 (aflP). Detection of aflatoxin biosynthesis genes in nine aflatoxigenic $A$. flavus and $A$. parasiticus isolates. In PCR technique, the tested primer pairs were shown in the presence of the given amplified fragments for 9 aflatoxigenic A. flavus and A. parasiticus isolates. All aflatoxigenic isolates shown appear as single DNA fragment, indicating the presence of the gene. PCR was used with four sets of primer pairs for nor-1, omt-1, ver-1, and aflR genes, enclosed in the aflatoxin biosynthetic pathway. Bands of the fragments of nor-1, ver-1, omt-1, and aflR genes can be visualized at 400, 537, 797, and $1032 \mathrm{bp}$, respectively (Figures $2,3,4$, and 5). The 67 isolates were analysed for the presence or absence of seven AF biosynthesis genes in relation to their ability to produce B1, targeting the two regulatory genes aflR and aflS and the five structural genes aflD, aflM, aflO, aflP, and $a f l Q$. The isolates were divided into 4 groups based on their patterns of PCR products: group one (40 strains) distinguished by presence of all seven genes; groups two (two strains) and three (nine strains) showing four (AflM, aflP, aflO, and aflQ) and three (aflO, aflP, and aflQ) amplicons, respectively; and group IV (16 strains) distinguished by total absence of PCR products.

\section{Discussion}

Three culture media were used to screen examined of Aspergillus isolates for aflatoxin production (Czapek agar, potato dextrose agar, and yeast extract sucrose agar). The presence or absence of fluorescence in the agar surrounding the colonies assayed was determined under UV light $(365 \mathrm{~nm})$

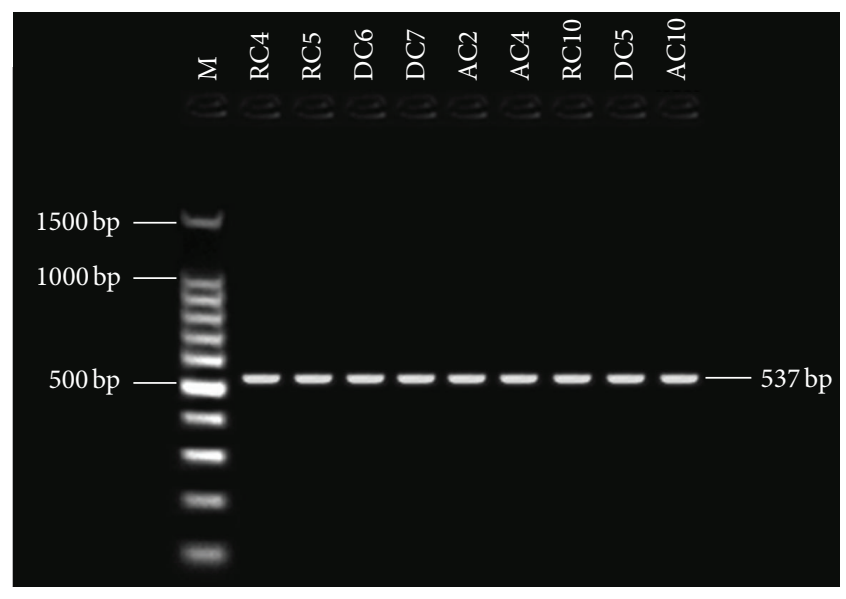

FIGURE 3: Gel electrophoresis analysis PCR products using aflR primer with $1032 \mathrm{bp}$, lanes from RC4 to AC4 (A. flavus), lanes from RC10 to AC10 (A. parasiticus), and lane M: 100 bp DNA ladder size marker.

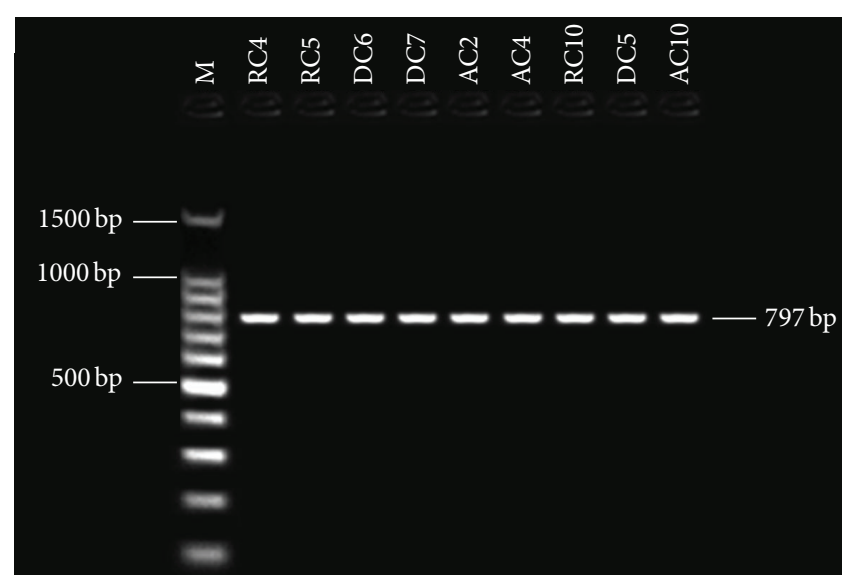

FIGURE 4: Gel electrophoresis analysis PCR products using ver-1 primer with $537 \mathrm{bp}$, lanes from RC4 to AC4 (A. flavus), lanes from $\mathrm{RC} 10$ to $\mathrm{AC10}$ (A. parasiticus), and lane M: 100 bp DNA ladder size marker.

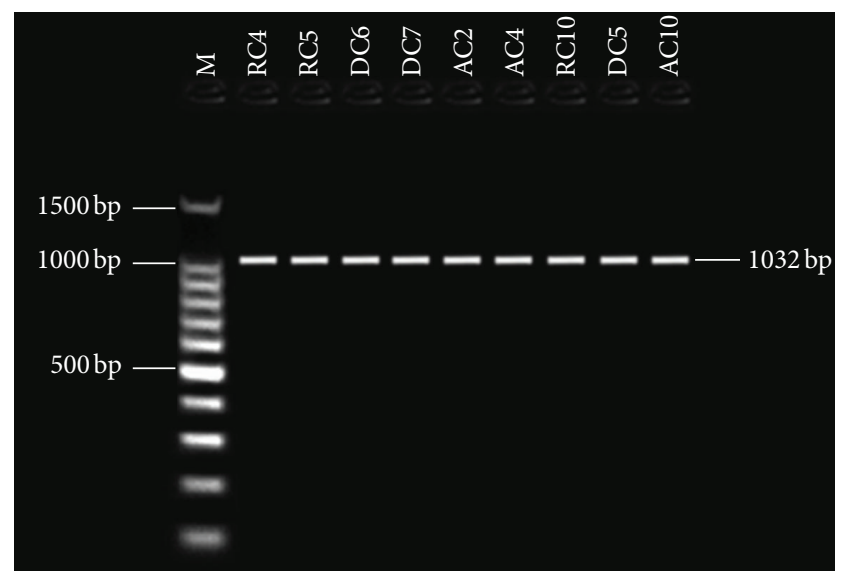

FIGURE 5: Gel electrophoresis analysis PCR products using omt-1 primer with $797 \mathrm{bp}$, lanes from RC4 to AC4 (A. flavus), lanes from RC10 to AC10 (A. parasiticus), and lane M: 100 bp DNA ladder size marker. 
[23]. Consequently, Aspergillus flavus and A. parasiticus were expressed as positive or negative, whereas all isolates of $A$. niger were expressed as negative. This result agrees with [24, 25]. Data show that the all tested essential oils (cinnamon, garlic, mint, rosemary, and thyme) appeared more effective on the growth at three tested doses compared to control. There is a direct relationship between the inhibitory effect of the oils and their doses [25-27].

Five tested essential oils that lead to a decrease in aflatoxins (B) were produced by A. flavus and A. parasiticus when compared with control. The results indicate that the test toxigenic fungi are sensitive to the 5 essential oils and particularly sensitive to thyme and cinnamon. This result is confirmed by many researchers [28-30].

The effect of essential oil might be due to aliphatic aldehydes and their ability to form charge transfer complexes with electron donors in the fungus cell [31]. Essential oil may be conducive to changes in the structure of the cells and denaturation of the enzymes which affects fungal morphogenesis and growth [32]. Essential oil leads to interference with the amino acid involved in germination [33]. Regional differences in aflatoxin contamination of crops may be attributable to climatic conditions and to agricultural practices that increase susceptibility of plants to invasion by A. flavus and relative humidity plays a vital role in the development and spread of fungal contaminations [34] and preharvest conditions of temperature and humidity in the field and improper postharvest handling and storage $[35,36]$.

Cluster genes in aflatoxin biosynthesis pathway contain structural genes, nor-1, ver-1, and omt-1, and aflR is a regulatory gene that plays a key role in the production of AF. The results indicated that three toxigenic isolates of $A$. flavus were positive using TLC technique and the appearing bands of the unique fragments of aflR, omt-1, ver-1, and nor-1 genes can be visualized at 1032, 1232, 895, and $400 \mathrm{bp}$, respectively. Positive results were obtained only with extracts of A. flavus, even at the lowest spore concentration. The elucidation of the results revealed that specific PCR for AF biosynthesis genes is of a high sensitivity and is rapid (100\%) [14, 37].

\section{Conflict of Interests}

The authors declare that there is no conflict of interests regarding the publication of this paper.

\section{Acknowledgment}

The authors would like to extend their appreciation to the Deanship of the Scientific Research at King Saud University for its funding of this research through the Research Group Project no. RGP-VPP-269.

\section{References}

[1] M. Doyle, L. Y. Beuchat, and T. Montville, Microbiologia de los Alimentos: Fundamentos y Fronteras, Acribia, Zaragoza, Spain, 2001.

[2] F. Requena, E. Y. Saume, and A. León, "Micotoxinas: enemigas silenciosas de la salud," Ceniap Hoy, vol. 9, p. 32, 2005.
[3] FAO, 2012, http://faostat.fao.org/site/339/default.aspx.

[4] P. Sekar, N. Yumnam, and K. Ponmurugan, "Screening and characterization of mycotoxin producing fungi from dried fruits and grains," Advanced Biotechnology, vol. 6, pp. 12-15, 2008.

[5] A. Kubatova, "Nové druhy toxinogenních penicilií nalezené na potravinách a jejích identifikace. (New species of toxinogenic Penicillium found in the foods and their identification)," in Sborník Prednášek: Aktuální Problematika Mikrobiologie Potravin II, pp. 103-107, Liblice-Byšice: Dum vedeckych pracovníku Akademie ved, 2000.

[6] K. M. Abdel-Gawad and A. A. Zohri, "Fungal flora and mycotoxins of six kinds of nut seeds for human consumption in Saudi Arabia," Mycopathologia, vol. 124, no. 1, pp. 55-64, 1993.

[7] P. A. Paranagama, K. H. T. Abeysekera, K. Abeywickrama, and L. Nugaliyadde, "Fungicidal and anti-aflatoxigenic effects of the essential oil of Cymbopogon citratus (DC.) Stapf. (lemongrass) against Aspergillus flavus Link. Isolated from stored rice," Letters in Applied Microbiology, vol. 37, no. 1, pp. 86-90, 2003.

[8] A. Kumar, R. Shukla, P. Singh, and N. K. Dubey, "Chemical composition, antifungal and antiaflatoxigenic activities of Ocimum sanctum L. essential oil and its safety assessment as plant based antimicrobial," Food and Chemical Toxicology, vol. 48, no. 2, pp. 539-543, 2010.

[9] J. H. C. Nogueira, E. Gonçalez, S. R. Galleti, R. Facanali, M. O. M. Marques, and J. D. Felício, "Ageratum conyzoides essential oil as aflatoxin suppressor of Aspergillus flavus," International Journal of Food Microbiology, vol. 137, no. 1, pp. 55-60, 2010.

[10] R. T. da Silva Medeiros, E. Gonçalez, R. C. Felicio, and J. D. Felicio, "Evaluation of antifungal activity of Pittosporum undulatum L. essential oil against Aspergillus flavus and aflatoxin production," Ciência e Agrotecnologia, vol. 35, no. 1, pp. 71-76, 2011.

[11] M. A. Passone, N. S. Girardi, and M. Etcheverry, "Antifungal and antiaflatoxigenic activity by vapor contact of three essential oils, and effects of environmental factors on their efficacy," $L W T$ Food Science and Technology, vol. 53, no. 2, pp. 434-444, 2013.

[12] A. Kedia, B. Prakash, P. K. Mishra, and N. K. Dubey, "Antifungal and antiaflatoxigenic properties of Cuminum cyminum (L.) seed essential oil and its efficacy as a preservative in stored commodities," International Journal of Food Microbiology, vol. 168-169, pp. 1-7, 2014.

[13] L. Czerwiecki, D. Czajkowska, and A. Witkowska-Gwiazdowska, "On ochratoxin A and fungal flora in Polish cereals from conventional and ecological farms. Part 1: occurrence of ochratoxin A and fungi in cereals in 1997," Food Additives \& Contaminants, vol. 19, no. 5, pp. 470-477, 2002.

[14] M. Erami, S. J. Hashemi, S. A. Pourbakhsh et al., "Application of PCR on detection of aflatoxinogenic fungi," Archives of Razi Institute, vol. 62, pp. 95-100, 2007.

[15] J. Yu, P.-K. Chang, K. C. Ehrlich et al., "Clustered pathway genes in aflatoxin biosynthesis," Applied and Environmental Microbiology, vol. 70, no. 3, pp. 1253-1262, 2004.

[16] N. D. Davis, S. K. Iyer, and U. L. Diener, "Improved method of screening for aflatoxin with a coconut agar medium," Applied and Environmental Microbiology, vol. 53, no. 7, pp. 1593-1595, 1987.

[17] C. M. Franco, C. A. Fente, B. I. Vázquez, A. Cepeda, G. Mahuzier, and P. Prognon, "Interaction between cyclodextrins and aflatoxins $\mathrm{Q}_{1}, \mathrm{M}_{1}$ and $\mathrm{P}_{1}$ :fluorescence and chromatographic studies," Journal of Chromatography A, vol. 815, no. 1, pp. 21-29, 1998. 
[18] U. L. Diener and N. D. Davis, "Aflatoxin production by isolates of Aspergillus flavus," Phytopathology, vol. 56, no. 12, pp. 13901393, 1966.

[19] E. O. Lima, O. F. Gompertz, A. M. Giesbrecht, and M. Q. Paulo, "In vitro antifungal activity of essential oils obtained from officinal plants against dermatophytes," Mycoses, vol. 36, no. 910, pp. 333-336, 1993.

[20] A. A. Mostafa, A. N. Al-Rahmah, and A. Abdel-Megeed, "Evaluation of some plant extracts for their antifungal and antiaflatoxigenic activities," Journal of Medicinal Plants Research, vol. 5, no. 17, pp. 4231-4238, 2011.

[21] G. Christian, HPLC Tips and Tricks, Iden Press, Oxford, UK, 1990.

[22] O. E. Amer, M. A. Mahmoud, A.-R. M. A. El-Samawaty, and S. R. M. Sayed, "Non liquid nitrogen-based-method for isolation of DNA from filamentous fungi," African Journal of Biotechnology, vol. 10, no. 65, pp. 14337-14341, 2011.

[23] P. A. Murphy, S. Hendrich, C. Landgren, and C. M. Bryant, "Food mycotoxins: an update," Journal of Food Science, vol. 71, no. 5, pp. 51-65, 2006.

[24] C. A. Fente, J. J. Ordaz, B. I. Vázquez, C. M. Franco, and A. Cepeda, "New additive for culture media for rapid identification of aflatoxin-producing Aspergillus strains," Applied and Environmental Microbiology, vol. 67, no. 10, pp. 4858-4862, 2001.

[25] M. F. Al-Gahtani, R. M. Al-Othman, M. A. Mahmoud, and A. R. M. Abd El-Aziz, "Anti-aflatoxigenic effect of essential oils on Aspergillus Spp. Isolated from pistachio in Saudi Arabia," African Journal of Microbiology Research, vol. 7, no. 25, pp. 31513159, 2013.

[26] C. S. Reddy, K. R. N. Reddy, M. Prameela, U. N. Mangala, and K. Muralidharan, "Identification of antifungal component in clove that inhibits Aspergillus spp. colonizing rice grains," Journal of Mycology and Plant Pathology, vol. 37, pp. 87-94, 2007.

[27] I. Rasooli, M. H. Fakoor, D. Yadegarinia, L. Gachkar, A. Allameh, and M. B. Rezaei, "Antimycotoxigenic characteristics of Rosmarinus officinalis and Trachyspermum copticum L. essential oils," International Journal of Food Microbiology, vol. 122, no. 1-2, pp. 135-139, 2008.

[28] O. O. Atanda, I. Akpan, and F. Oluwafemi, "The potential of some spice essential oils in the control of $A$. parasiticus CFR 223 and aflatoxin production," Food Control, vol. 18, no. 5, pp. 601-607, 2007.

[29] S. Rad, H. Afshari, M. M. Moghadam, S. Tahmasbi, H. Ziaolhagh, and A. Ebadi, "The study of antifungal effects of herbal essences on Aspergillus parasiticus, an aflatoxin producer in pistachio (Pistacia vera)," Journal of Medicinal Plant Research, vol. 5, no. 20, pp. 5155-5159, 2011.

[30] M. Eweis, A. A. Imhemmed, and A. S. Gad, "Influence of Thymus serpyllum essential oil on Aspergillus parasiticus morphology and aflatoxins production," Research Journal of Pharmaceutical, Biological and Chemical Sciences, vol. 3, no. 2, pp. 322-332, 2012.

[31] I. Rasooli, M. B. Rezaei, and A. Allameh, "Ultrastructural studies on antimicrobial efficacy of thyme essential oils on Listeria monocytogenes," International Journal of Infectious Diseases, vol. 10, no. 3, pp. 236-241, 2006.

[32] B. Ghfir, J. L. Fonvieille, and R. Dargent, "Influence of essential oil of Hyssopus officinalis on the chemical composition of the walls of Aspergillus fumigatus (Fresenius)," Mycopathologia, vol. 138, no. 1, pp. 7-12, 1997.
[33] G. J. E. Nychas, "Natural antimicrobial from plants," in New Methods of Food Preservation, G. W. Gould, Ed., pp. 58-89, Blackie Academic \& Professional, Glasgow, UK, 1995.

[34] L. S. Nawar, "Prevention and control of fungi contaminated stored pistachio nuts imported to Saudi Arabia," Saudi Journal of Biological Sciences, vol. 15, pp. 105-112, 2008.

[35] V. K. Nakai, L. D. O. Rocha, E. Gonçalez, H. Fonseca, E. M. M. Ortega, and B. Corrêa, "Distribution of fungi and aflatoxins in a stored peanut variety," Food Chemistry, vol. 106, no. 1, pp. 285290, 2008.

[36] S. Khodavaisy, A. Maleki, B. Hossainzade et al., "Occurrence of fungal contamination in pistachio and peanut samples from retail shops in Sanandaj province," African Journal of Microbiology Research, vol. 6, pp. 6781-6784, 2012.

[37] A. Gallo, G. Stea, P. Battilani, A. F. Logrieco, and G. Perrone, "Molecular characterization of an Aspergillus flavus population isolated from maize during the first outbreak of aflatoxin contamination in Italy," Phytopathologia Mediterranea, vol. 51, no. 1, pp. 198-206, 2012. 

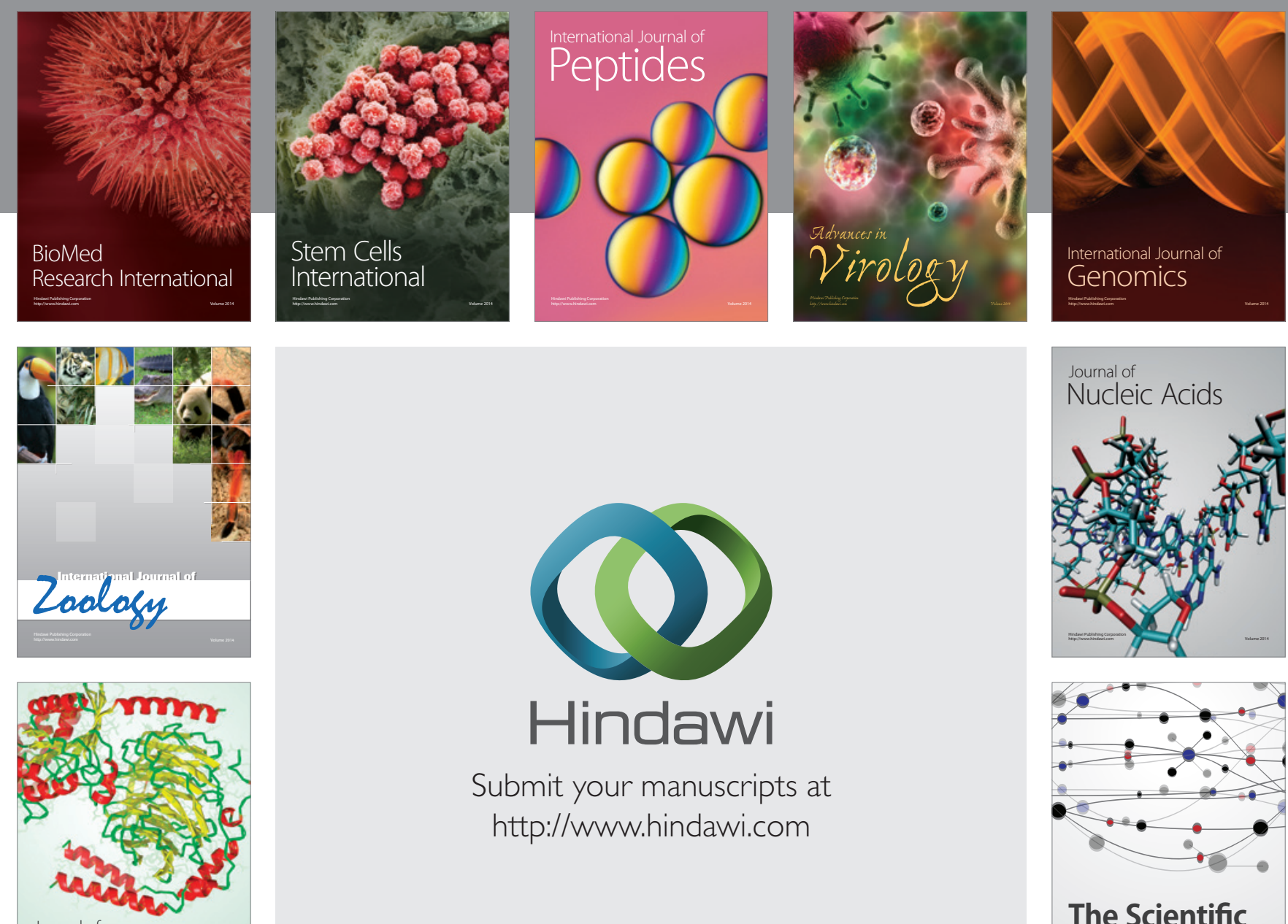

Submit your manuscripts at

http://www.hindawi.com

Journal of
Signal Transduction
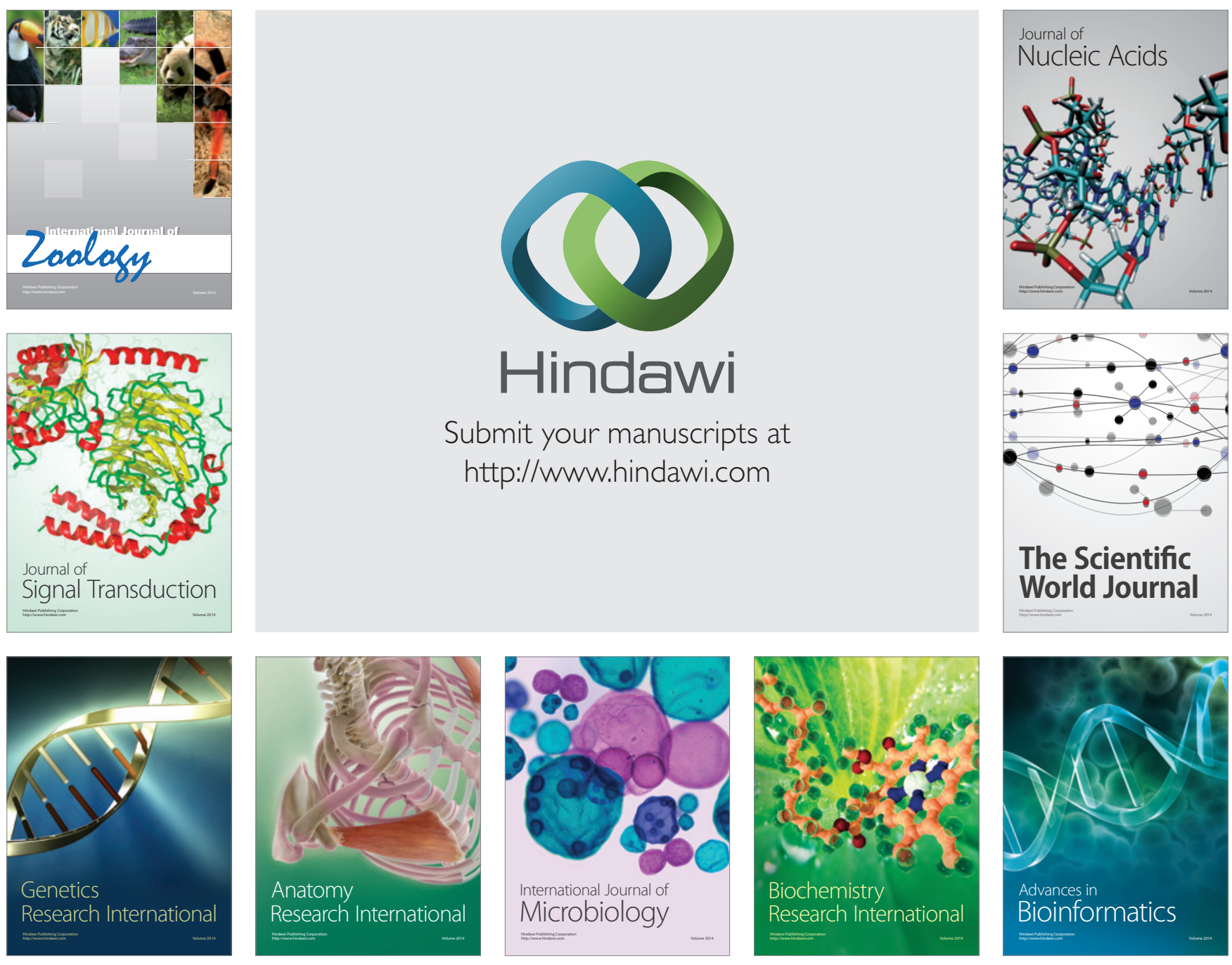

The Scientific World Journal
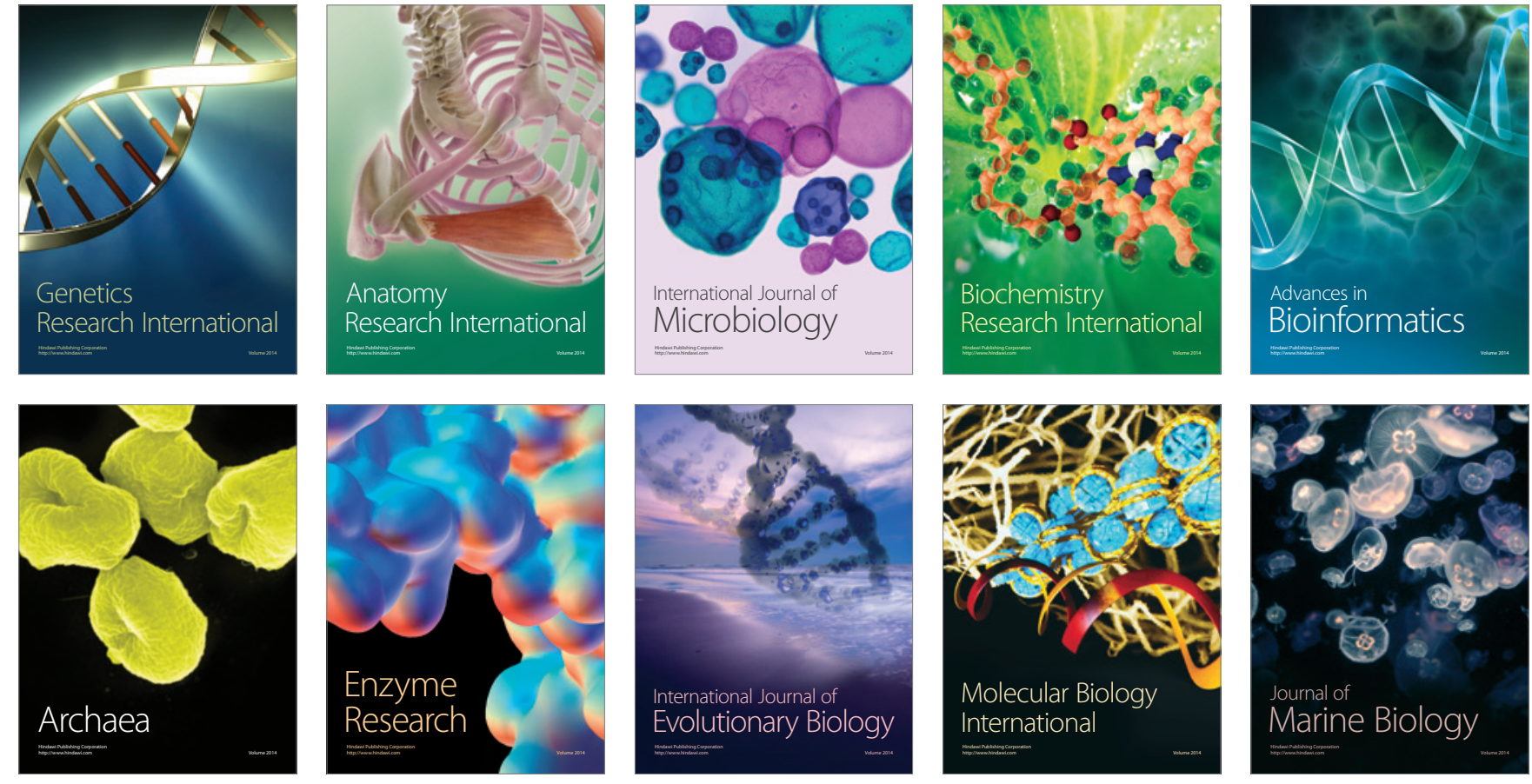